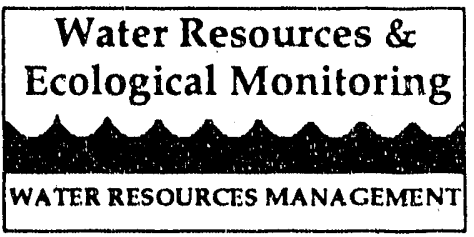

\title{
Status of Norris Reservoir
}

\section{An Overview of Reservoir Conditions}

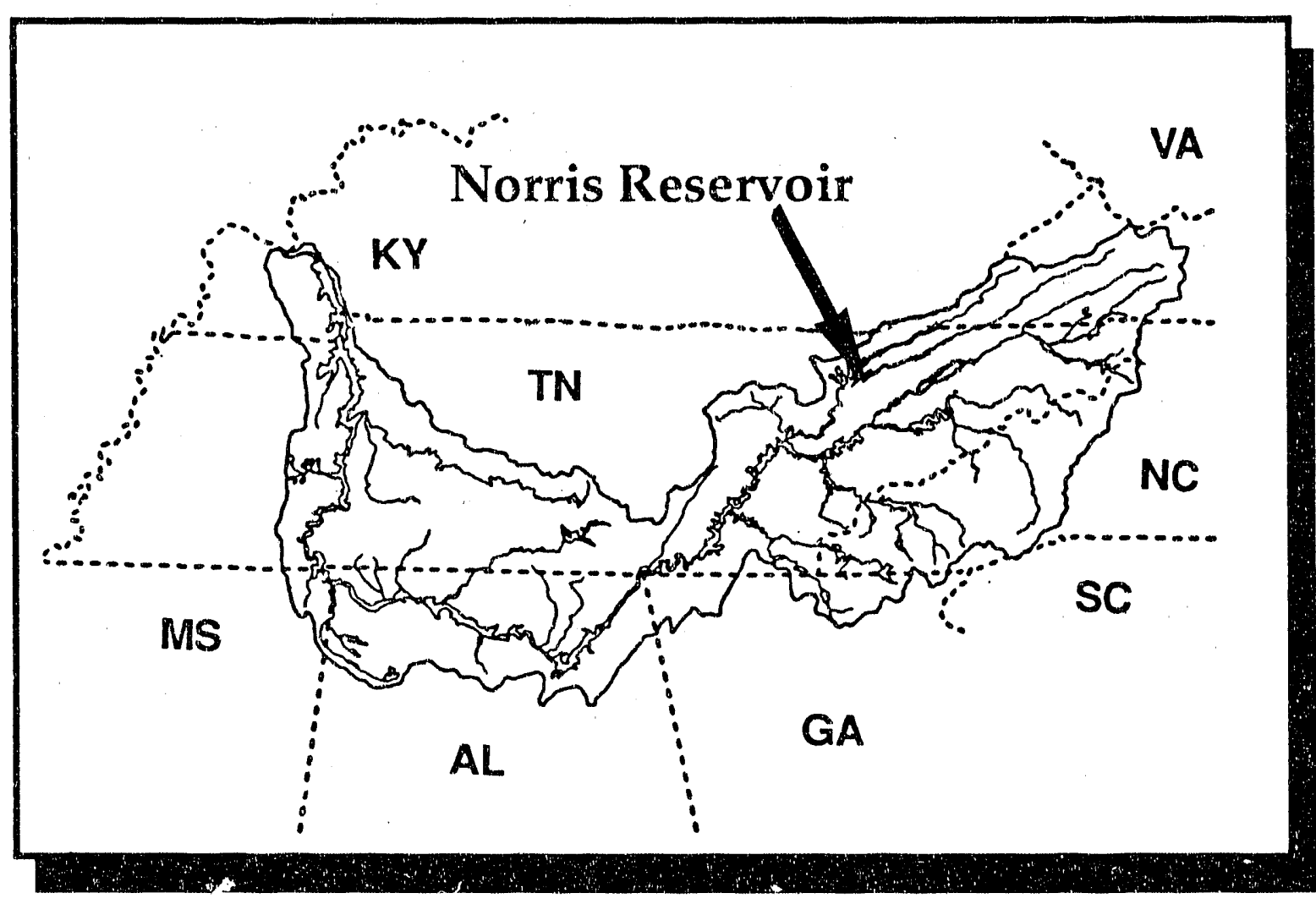

Tennessee Valley Authority

Resource Development

River Basin Operations

Water Resources Division

September 1990 
TVA/WR/WQ--90/19

Tennessee Valley Authority. Water Resources Division.

Page

Introd

Chat tanooga, TN

$\ldots 1$

Purpos

Norr

.. 3

Description of Watershed and Reservoir Area................................. 5

Reservoir Characteristics and Jses..................... 8

Water Quality and Biological Conditions..................... 14

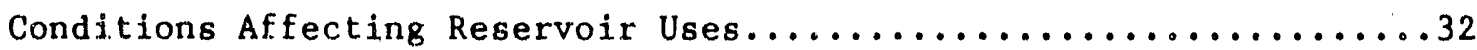

Selected Reservoir Management Agencies........................ 33

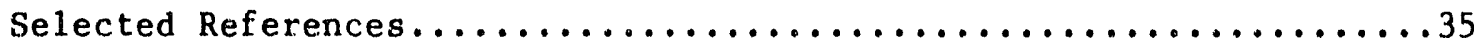


INTRODUCTION

This is one in a series of reports prepared by the Tennessee Valley Authority (IVA) for those interested in the conditions of TVA reservoirs. This overview of Norris Reservoir surmarizes reservoir and watershed characteristics, reservoir uses, conditions that impair reservoir uses, water quality and aquatic biological conditions, and activities of reservoir management agencies. This information was extracted from the most up-to-date publications and data available, and from interviews with water resource professionals in various federal, state, and local agencies, and in public and private water supply and wastewater treatment facilities.

Norris Reservoir was completed in 1936 as TVA's first multipurpose water resources project. It is operated to maintain downstream navigation, control downstream flooding, and generate hydropower. The reservoir is also operated to provide other public and private uses for overall regional economic growth and developinent fncluding water supply, water quality, recreation, fish and aquatic habitat, develoment of shorelands, and aesthetic quality. The reservoir and tailweiter support several popular warm-, cool-, and coldwater fisheries including black bass, sunfish, crappie, walleye, striped bass, rainbow trout, and brown trout.

The water quality conditions of Norris Reservoir are suitable for the various uses identified. However, several water quality conditions adversely affect the beneficial uses of Norris Reservoir. Strong thermal stratification and depletion of dissolved oxygen in the bottom layer of the reservoir seasonally reduce the amount of habitat suitable for $f$ ish and other aquatic life. The resulting low dissolved oxygen in releases from the dam affect both aquatic life and the Clinch River's capacity to assimilate organic materials present in runoff and wastewaters. Fluctuations in water level in both the reservoir and tailwater and 
variable flow rate in the tailwater affect recreation, aquatic life, shoreline development, and aesthetic quality. The oligotrophic, or low productivity, nature of the reservoir limits the fishery potential of the reservoir.

Other conditions that have not been fully evaluated potentially affect the beneficial uses of Norris Reservoir. In the bottom layers of the reservoir, concentrations of iron and manganese may increase to levels that would require extra treatment for use as a water supply. In addition, sediment loads that contain heavy metals from mining operations In combination with agricultural runoff potentially affect aquatic life, water supply, and recreation.

Management of Norris Reservoir is a responsibility shared among several agencies including TVA, the Tennessee Department of Health and Environment (TDHE), and the Tennessee Wild1ife Resources Agency (TWRA). These agencies investigate, monitor, and attempt to mitigate those conditions impairing reservoir uses. In addition, several citizen organizations are involved in protecting water quality and beneficial uses of Norris Reservoir, including Friends of the Clinch-Powel1 (FC-P) and Citizen League for Environmental Action on Norris Lake (C.L.E.A.N.). 
PURPOSE AND OPERATION OF NORRIS DAM AND RESERVOIR

Norris Dam is located at Clinch River mile (CRM) 79.8 in Campbell and Anderson Counties, Tennessee. It impounds a 73-mile reach of the $\mathrm{Clinch}$ River (CRM 79.8 to 153) and a 56-mile reach of the Powell Rives (PRM 0 to 56), a major tributary that joins the Clinch at CRM 88.8. Norris Reservoir, therefore, has two large arms with a total length of 129 miles (see centerfold map).

Norris Reservoir is operated primarily to control downstream flooding during the rainy winter and spring, to iid downstream navigation during the dry summer and $\{a 11$, and--whenever it does not interfere with flood control or navigation--to generate electricity. To the extent that there is no conflict with these primary objectives, Norris Dam is also operated to achieve other secondary objectives including water supply, water. quality, recreation, aquatic and wildlife habitats, sport fisheries, development of shorelands, and aesthetic quality.

The normal annual operation cycle of Norris Dam and Reservoir includes releasing water through summer and fall to generate hydropower during periods of high power demands and to draw the reservoir to its January 1 flood control level for storage of runoff from heavy winter rains (see following figure). In early spring, as the risk of floods lessens, the reservoir is allowed to refill. It usually reaches its highest level during May or early June. Pool levels can vary by 50 feet during the year depending on rainfa11 and power demands, but the water level normally fluctuates only about 32 feet.

Special reservoir operations are ocasionally scheduled to accommodate specific needs such as for repair and maintenance of the dam and power house and a reregulation weir located two miles (CRM 77.9) below Norris Dam, special fisheries and recreational activities, and water quality studies. Special discharges are also scheduled to maintain requirea flows past TVA fossil and nuclear plants. In addition, a minimum flow of 200 cubic feet per second (cfs) is provided to enhance the tailwater 
fishery. During extended periods without power generation, one turbine is operated briefly twice a day to refill the reregulating pool, which ensures this flow is met.

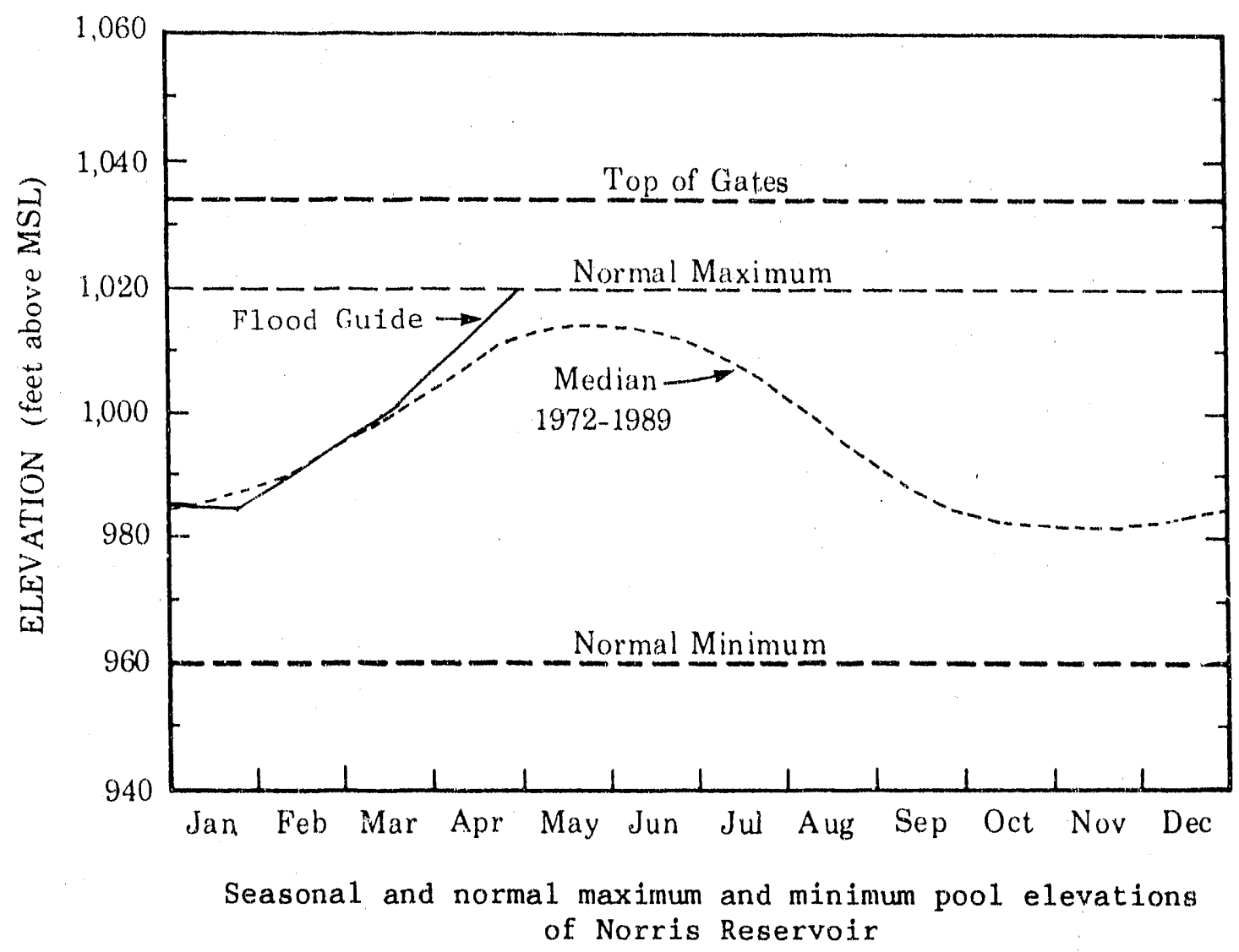

Lake level studies were conducted by TVA in 1987-88 in response to public requests that winter pool levels be raised from elevation 960 to 990 in the interest of reservoir recreation, which would allow greater access to the water and the development of several additional tracts of land. No decision was made to raise the winter pool levels because of the reduced flexibility of using the water to generate hydropower during peak demand periods in winter, the significant cost associated with replacing the hydropower with other more costly sources of power, and the reduced flood storage capacity that could result in local flooding in the area of Clinton, Tennessee.

In response to growing public pressure, TVA now is considering a proposal to maintain higher, more stable summer lake levels to increase recreation benefits (TVA, 1990). 
DESCRIPTION OF WATERSHED AND RESERVOIR AREA

Watershed Characteristics

Norris Reservoir receives drainage from a total of 2,912 square miles in Virginia and Tennessee. The largest tributary to Norris Reservoir is the Powel1 River, which has a total drainage area of 938 square miles. other major tributaries include: Big Creek (CRM 83) which drains 67.3 square miles and Cove Creek (CRM 76.8) which drains 60.8 square miles. The impounded portion of Big Creek and Cove Creek are deep at the mouth (about 130 to 150 feet), extend about 16 miles upstream, and behave like small reservoirs. Several smaller creeks drain the narrow valleys of the reservoir area.

Norris Reservoir parallels the Cumberland Plateau to the northwest and the Clinch Mountains to the southeast. Rock formations in the area are primarily limestone, dolomite, shale, and sandstone. Knox dolomite forms the steep--sided ridges with narrow valleys characteristic of the region. The continuous valleys are underlain by several different limestones. Solution channels in the limestone provide for underground water flow which in some cases returns to the surface as springs that contribute to surface streams. Caves and sinkholes are common in the area; the latter are ocasionally used for wastewater discharge. The parallel ridges and narrow intervening valleys favor quick run-off, which contributes to nompoint source pollution associated with land use activities. The elongated shape of the basin tends to delay the concentration of flood flows. Elevations in the Clinch River watershed range from 800 feet above mean sea level (MSL) in the lower portion of the basin to more than 4,000 feet above MSL in the headwaters in southwest Virginia.

Annual precipitation averages about 47 inches for the $\mathrm{Clinch}$ watershed, a little less than the Tennessee Valley average of 51 inches. July is usually the rainiest month ( 5.1 inches), and 0ctober ( 2.4 inches) is the driest. January averages 4.2 inches. Runoff averages about 41 percent of rainfall. Average runoff from the Powell watershed (1.6 cfs $\left./ \mathrm{mi}^{2}\right)$ is slightly higher than that from the Clinch $\left(1.4 \mathrm{cfs} / \mathrm{mi}^{2}\right)$. 
Forestry, agriculture, and coal mining are the predominant land uses that support the local economy in the Clinch River basin. About 65 percent of the Clinch watershed is forest land particularly in the headwater area, about 25 percent is agricultural land mostly in the lower portions of the basin, 1 percent is urban development, less than 5 percent is characterized by past and present mining activity, and 4 percent is devoted to other uses. Land disturbances aiter both the quality of the water draining from a watershed and the amount that percolates into the ground rather than running of $\mathrm{f}$ drectly into a stream.

Agricultural activities in the watershed create nonpoint source pollution (runoff from land uses). Forest cutting and construction and surface-mining activities also contribute large quantities of sediment to nearby streams. Runoff and seepage from improperly mined or unreclaimed strip-mined areas, in addition to carrying sediment, contain iron and sulfate, and may be acidic enough to adversely affect the streams they enter. Crushed 1 imestone and dolomite are also produced in the area along with minor amounts of sand, gravel, and marble. Iron ore, zinc, and limited amounts of natural gas and oil have been produced. It is not known how much of these nonpoint source materials eventually get into streams and Norris Reservoir, let alone affect the water quality.

Norris Reservoir impacts a 5-county area including portions of Anderson, Campbe11, Union, Claiborne, and Grainger Counties in northeastern Tennessee. Estimated population of the area in 1988 was 161,600. The area is experiencing moderate growth. The largest city is Oak Ridge $(27,720)$ in Anderson County. Other towns with populations greater than 5,000 include clinton $(8,860)$ and LaFollette $(7,950)$. The city of Knoxville (population 172,080 ) is located approximately 26 miles to the suutheast.

\section{Shoreline Characteristics}

Shoreline development directly affects the water quality of Norris Reservoir. At full pool Norris Reservoir has 750 miles of shoreline. Islands in the reservoir have a combined shoreline length of 50 miles. 
Shorelines are mostly steep, wooded bluffs. About 60 of the 251 miles of privately owned shoreline has been developed for residential uses. Most residential development is concentrated along the lower end of the reservoir on the Clinch River arm. Residential development on the Powell arm has been limited because most of the land is publicly owned. Most shoreline homes have septic tanks with subsurface drainfields. Stressed or failing systems or those installed improperly adversely affect local water quality.

TVA owns about 22,000 acres of land around Norris Reservoir and has flowage easements which allow TVA to flood the land to a certain elevation on about 5,000 acres. Owning land around the reservoir allows TVA to positively influence development on adjacent lands by controlling access to the reservoir. TVA owns several large tracts, including a 1,100-acre tract in the Loyston Point area and a 500-acre tract on Island F'. Because of the large tracts of land available, TVA has forest and wil'ife management projects throughout the reservoir area. About 21,600 acres of the TVA property are forested, mainly with hardwoods.

Recreational facilities include 3 state parks, 4 county parks, 3 municipal parks, 59 public access areas, 24 commercial recreation areas and docks, 6 natural areas, 6 trails, 5 group camps and clubs, and 2 state wildlife management areas. In 1988, these facilities provided about 1,010 campsites, 260 picnic areas, 3 beaches, 139 lodging units, and 3,700 slips for houseboats, sailboats, and runabouts. The two state wildlife management areas are Chuck Swan Wildlife Management Area, a 24,000-acre area between the $\mathrm{C} 1$ inch and Powe11 Rivers and Cove Creek Peninsula Wildlife Management Area, a 2,600-acre area on the lower portion of the reservoir.

Industrial development in the area has been limited. Most of the existing industries are manufacturing firms. 


\section{Physica1 Characteristics}

Norris Reservoir is TVA's largest tributary storage impoundment. In the TVA system, only Kentucky Reservoir, on the mainstem Tennessee River, has more storage capacity. The physical characteristics of Norris Reservoir are summarized below.

\begin{tabular}{lr} 
Feature & Measurement \\
\cline { 2 - 2 } $\begin{array}{l}\text { Location of Dam, Clinch River mile } \\
\text { Impounded Reach }\end{array}$ & 79.8 \\
C1inch River mile & 79.8 to 153 \\
Powe11 River mile & 56 \\
Normal maximum pool elevation, & 1020 \\
feet above mean sea leve1 & \\
Surface area, acres & 34,200 \\
Volume, acre-feet & 20,000 \\
Maximum depth, feet & 54 \\
Average depth, feet & 12.9 \\
Length, miles & 750 \\
Shoreline length, miles & 50 \\
$\quad$ Islands, miles & 960 \\
Normal minimum pool elevation, & \\
feet above mean sea level & 14,900 \\
Surface area, acres & 630,000 \\
Volume, acre-feet & \\
Useful controlled storage volume, & \\
acre-feet (elevation 1034-960) & 1522,000 \\
Average hydralic & \\
retention time, days & 13.6 \\
Tailwater length, miles &
\end{tabular}

Hydroiogic Characteristics

Average monthly inflows vary from about $1,200 \mathrm{cfs}$ in October to about 7,120 cfs in January. Historical yearly (1921-86) average is about $4,160 \mathrm{cfs}$. Releases from the dam generally are regulated within the range of 0 to $8,400 \mathrm{cfs}(4,200 \mathrm{cfs}$ per turbine). About 30 percent of the total inflow comes from the Powell River basin, with the clinch providing the remaining 70 percent. 


\section{Norris Dam Tailwater}

The Norris Dam tailwater extends more than 13 miles downstream from the dam to the headwaters of Melton Hill Reservoir (CRM 79.8 to 66.2). Average width of the channel ranges from 310 feet (low flow conditions) to 432 feet. (two turbine generation). Flows are generally regulated within the range of 200 to $8,400 \mathrm{cfs}$. On-and-off releases for hydropower generation cause severe fluctuations in streamflow. Water level fluctuates about 6 feet depending on turbine generation. Bedrock is the predominant substrate in the tailwater with small patches of rubble, gravel, and cobble.

\section{Uses of Norris Reservoir}

The principal uses of Norris Reservoir are for navigetion, flood control, and hydroelectric generation. However, Norris Reservoir also supports many secondary uses such as recreation, water supply, habitat for aquatic life, sport fishing, and shoreline development.

The Tennessee Department of "Tealth and Environment (TDHE) has assigned we classifications to Norris Reservoir and its tributaries. These classifications determine the criteria and standards used in regulating watewater discharges and determining the acceptability of water quality. TDHE classifies Norris Reservoir for domestic water supply, industrial water supply, fish and aquatic life, recreation, irrigation, and livestock and wildife watering . In addition, TDHE classifies White Creek (mile 0.0 to 2.0), Clear Creek (mile 0.0 to 2.0), and the tailwater below Norris Dam (CRM 79.8 to 66.2 ) as trout $s$ treams.

Navigation. Commercial navigation locks are not included at Norris Dam. Reservoir rel.eases help to meet downstream navigation requirements on the Tennessee River. Normal operations for flood control and power generation usually provide adequate streamflow to meet navigation requirements. Under drought conditions, special releases are provided for navigation.

Flood Control. Norris Reservoir provides significant flood regulation at many locations downstream, most importantly for the area around 
Chat tanocga, Tennessee. The reservoir has a seasonally varying reserved flood detention capacity, with a maximum of 1.47 million acre-feet in January .

Hydroelectric Power. Hydroelectric power is generated $r y$ two turbines in Norris Dam that have a total installed capacity of 100.8 megawats, about 3 percent of the total hydropower capacity of the TVA system. Because hydropower generation is the most economical, versatile, and dependable power source in the TVA system, it is used to provide peaking power quickly for those times of day when power demands are highest. Seasonal demands are greatest from June through August and from December through February. Late winter and spring flows are stored to meet the peak power demands of summer. Operations at Norris also help regulati inflows to all downstream hydroelectric plants from Melton Hill Dam on the Clinch River to Kentucky Dam near the mouth of the Tennessee River.

Recreation. Recreational use of Norris Reservoir exceeds that of any other TVA tributary reservoir. The reservoir received an estimated 3.4 million day-visits in 1986. Fishing, swimming, waterskiing, and boating are the primary recreation activities on the reservoir. Creel data indicate an average of 106,000 fishing trips to the reservoir each year and an average fish harvest of 180,000 pounds. Important sportfish include largemouth, smal1mouth, and spotted bass; white and black crappie; walleye; white and siriped bass; and bluegill. Norris Reservoir is closed to commercial fishing. A limited trotline fishery exists primarily for flathead catfigh.

Rainbow and brown trout are stocled in the tailwater by TWRA. Creel. surveys indicate approximately 30,000 fishing trips are made to the tailwater area each year, making it the most important managed trout stream in Tennessee.

Increased fishing pressure produced the need for more timely information about current and flow conditions, especially because 90 percent of all fishing occurs during low flow conditions. A computeractivated Voice Response system was installed in 1988 to provide. continuous 
information by telephone $(615 / 632-2264,-2265,-2266,-2268$, or -2174 , plus 11 for Norris Reservoir) of the daily schedule for releases at 42 dams. Requests for information abisut discharge schedules at Norris accounted for more than 56 percent of the 138,174 requests received in 1989 .

Related shoreline activities include picniking, camping, hiking, sightseeing, and nature-watching. Total cumulative public and private investments in recreational facilities increased from $\$ 50$ million in 1978 to more than $\$ 77$ million in 1988 . There is increasing interest in recreational floating of the Norris Dam tailwater using rafts, canoes, and kayaks TVA is currently investigating the feasibility of providing specia releases i selected weekends for recreational floating below Norris Dam.

Support for Biological Commities. The fish and other aquatic life community of Norris Reservoir is stable, diverse, and moderately productive. The Clirch Biver watershed suppurts some of the most diverse freshwater communities in the world. The upper portions of the yatershed are inhabited by populations of aquatic insects, mollusks, fish, and other animals and plants that no longer exist in the rest of the Tennessee River system. The $\mathrm{Clinch}$ River has about $101 \mathrm{fish}$ species and 50 mussel species, while the Powell 1 iver has $66 \mathrm{fish}$ species and 37 mussel species. The $\mathrm{Clinch}$ arm tas the greatest number of freshwater mussel species remaining in the upper portions of the Tennessee River System (Tennessee/Virginia Task Force Draft Report, 1987). This natural diversity persists because most of the watershed has not been developed for human use as much as other river valleys in the region.

Hater Supply. Several surface water supply intakes located in Norris Reservoir or its local tributaries (see following table) withdraw about 4.7 million gallons per day (mgd). Increasing domestic witer needs because of increased population, excessive siltation from strip-mine runoff, and drought effects on flow rates of local springs used for water supplies are forcing municipalities and industries to consider alternate sources, including Norris Reservoir. In 1988, TVA identified water supply 
alternatives for Lafollette and the potential for a regional water supply for the area including Caryville, Jacksboro, LaFollette, and the Powell Valley. LaFollette has developed plans and requested bids for construction of a 4-mgd water treatment plant with an intake on Norris Reservoir.

Several small commercial facilities also have intakes in the area. Most local industries rely on municipal supplies for potable and process water. Use of Norris Reserroir for agricultural water supply is 1 imited and poorly documented.

Water Treatment Plant

Hickory Star Marina

Claiborne County Utility District

Anderson County Park

Stardust Dock

LaFollette Utilities Board

Jacksboro Utility District

Jackcboro Utility District

Norris Dam State Park

Caryville-Jacksboro Utilities

Conmission
Intake location

Poor Land Valley

Creek mile 0.5

CRM 133.3

CRM 87.3

CRM 91.0

011 is Creek mile 1.8

Cove Creek 16.6

Cove Creek 13.6

Cove Creek 2.6

Cove Creek 10.3
Average daily use, mgd

$<0.01$

$2.50^{\mathrm{a}}$

$<0.01$

$<0.01$

1.70

0.72

0.14

0.10

2.00

a. Plant uniler construction will withdraw maximum of $2.5 \mathrm{mgd}$ from Norris Reservoir

Wastewater Assimilation. Several small towne discharge to Norris Resermir. None has a design capacity greater than $1 \mathrm{mgd}$, and most are located on tributaries. Four additional facilities (Norris Dam State Park, Sequoyah Lodge and Marina, Inc, Tennessee Department of Conservation, and Norris Dam) discharge less than $0.01 \mathrm{mgd}$.

Water Treatment Plant

Caryville-Jacksboro Utilities Commission

LaFollet te

Cumberland Gap

\section{Discharge location}

Cove Creek mile 15.8

Big Creek mile 17.8

Powell River mile 54.6
Average discharge, mgd

0.86

0.84

0.16 
At some boat docks noored recreational boats equipped with marine toilets discharge :reated or untreated sewage directly into the reservoir. There are no pump-out facilities on the reservoir for adequate disposa? of boat wastes.

No industry discharges into Norris Reservoir. Industries discharge to municipal waste treatment plants. Powel1 Valley Foods, Lincoln Brass Works, and Furtex Corporation discharge to the Caryville-Jacksboro Utility Commission waste treatment plants; and American Metals, Imperial Reading, and $M$ and $M$ Polishing and Plating discharge to the Lafollette waste treatment plant. 
WATER QUALITY AND BIOLOGICAL CONDITIONS

TVA conducted extensive investigations of Norris Reservoir in the late 1930s. These studies included determining the physical, chemical, and biological conditions of the reservoir, and how they might best be managed. Few investigations have been conducted on Norris Reservoir since the 1930s. In 1979 tropi ic status studies were conducted on several TVA reservoirs, including Norris. The only recent water quality data is from a drought study that was conducted ruring the sumere of 1986 and 1988 and a reservoir "vital signs" monitoring project that TVA initiated in 1990. The "vital signs" project includes three stations on Norris Reservoir (CRM 80, CRM 125, and PRM 30), which are monitored in January and April through September of each year. The purpose of the "vital signs" projecl is to provide information on the overall health of each reservoir monitored. Available reports, data retrieved from STORET (the U.S. Environmenta1 Protection Agency's computer file of data collected by state and federal agencies), recent monitoring results, and personal interviews form the basis for the following discussion.

\section{I'emperature and Dissolved Oxygen}

Thermal stratification and dissolved oxygen depletion is a natural process that affects water quality and biological conditions in most deep storage impoundments. During the warmer months of the year, Norris Reservoir becomes thermally stratified (divided into cold and warm layers). Layering begins in late spring and becomes more pronounced in summer as the sun warms surface waters, which become less dense and no longer mix with the colder, denser layers of water below. In summer, temperatures is the surface layer or epilimnion range from $76^{\circ} \mathrm{F}$ to $84^{\circ} \mathrm{F}$, while those in the bottom layer or hypolimnion range from $46^{\circ} \mathrm{F}$ to $54^{\circ} \mathrm{F}$. Stratification generally ends by late fall, as decreasing air temperatures cool the surface water, which becomes more dense, sinks, and mixes with the bottom layer. In winter, with further coolin, and mixing, temperatures become relatively uriform from surface to botton, averaging about $46^{\circ} \mathrm{F}$. 


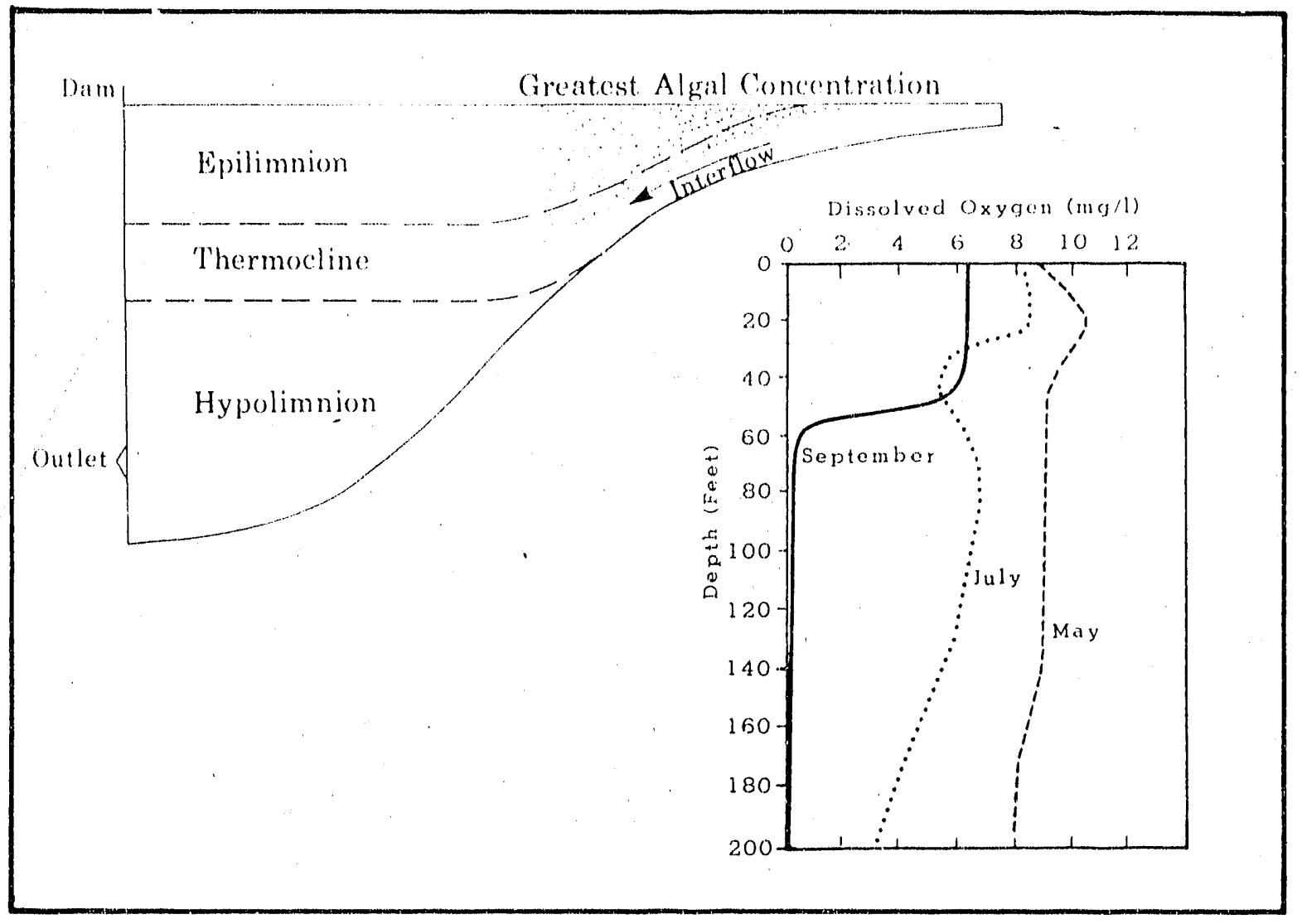

Typical temperature and dissolved oxygen stratification in Norris Reservoir

During stratification, chemical and bacterial processes in the reservoir water and sediment deplete the dissolved oxygen in the bottom layer of cold water. Because the bottom water does not mix with the warm surface water during the summer, no "fresh" oxygen (from atmospheric aeration or photosynichesis) replenishes that used up by those chemical and bacterial processes. Consequent1y, dissolved oxygen concentrations in the bottom water drop to low levels. As the top layer cools and sinks to the bottom in the fall, the vertical mixing that occurs replenishes the oxygen in the bottom water.

In summer, dissolved oxygen concentrations in the bottom layer of the reservoir and in releases through hydroelectric turbines to the river below the dam decrease to less than $1 \mathrm{mg} / 1$. This forces coldwater species of fich to move up into a narrow zone near the thermocline or 
into embayments where adequate temperatures and dissolved oxygen are present. In extreme cases, crowding can stress fish and result in emaciation, disease, and ultimately death. Conditions in Norris Reservoir are not usually so severe as to produce this pattern of events. Other conditions that may be associated with low dissolved oxygen are releases of hydrogen sulfide, iron, and manganese from sediments. High concentration of these also adversely affect aquatic life, contribute to slime growth in turbine'systems, and require extra treatment of water supplies to avoid problems of taste, odor, and staining.

\section{Point Source Pollution}

Point source pollution from municipal and industrial discharges is not currently a significant problem in Norris Reservoir. Current impacts are limited primarily to two embayments. Wastewater discharges from moored houseboats may have adverse effects on water quality in the vicinities of marinas, but very little data are available to address this issue. Illegal dumping of wastes from oil and gas well drilling sites into streams in the Powell River basin also is a concern because of the potential impact on embayments, but is difficult to address because of its transient nature and a lack of data.

\section{Nonpoint Source Pollution}

Nonpoint source pollution pótentially could have a greater effect than point source pollution on water quality in Norris Reservoir. This type of pollution includes soil erosion from fields, pastures, construction sites, harvested timberlands, and mined lands; washoff of fertilizers and pesticides; and runoff of manure and sediment from feedlots, dairies, other livestock operations, and failing residential septic systems. Nonpoint sources of pollution are important to the quality of streams in the Norris Reservoir watershed. At present, the extent of nonpoint source pollution on water quality in Norris Reservoir has not been fully evaluated. 


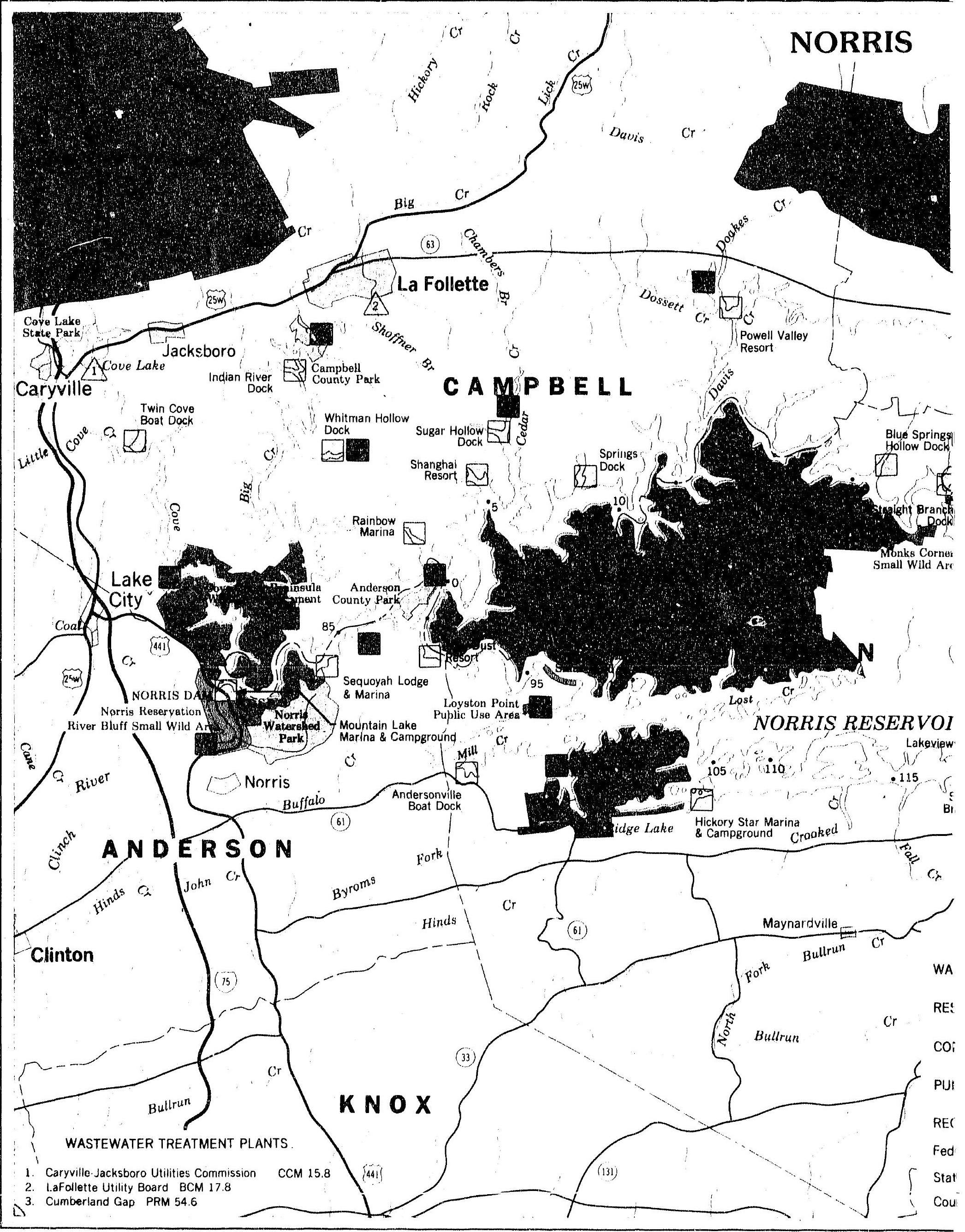




\section{ESERVOIR}

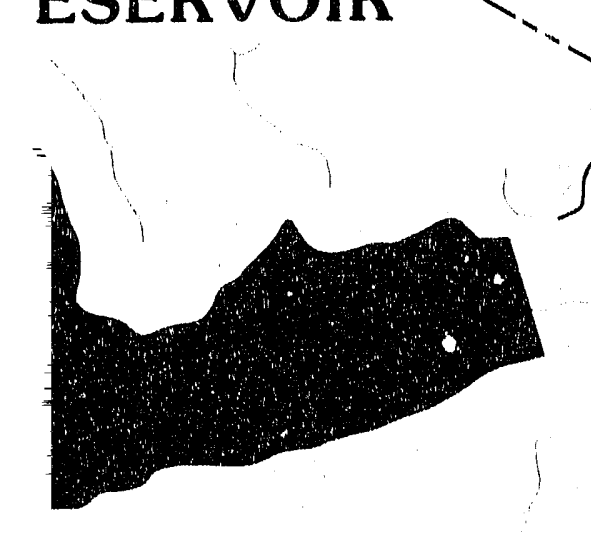

(63)

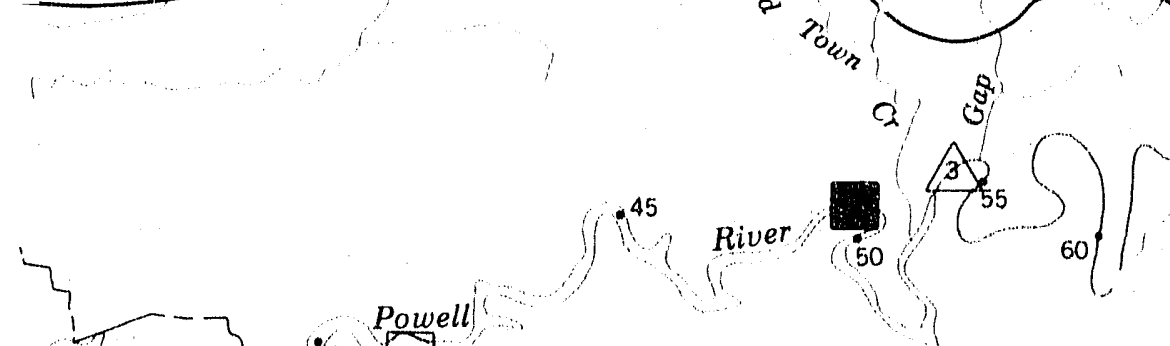
MIDDLESBORO
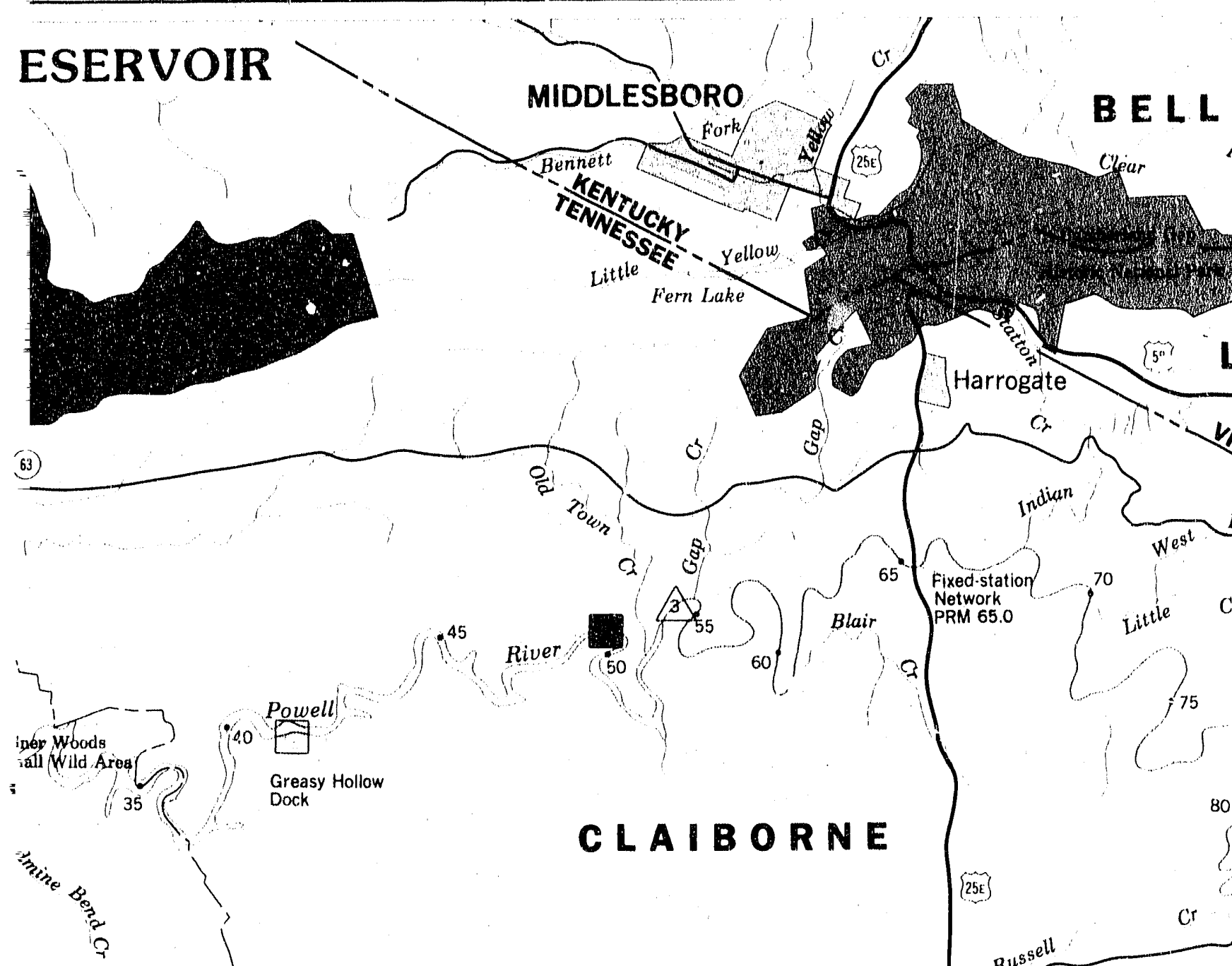
TVA uses color infrared photography to inventory land-uses and nonpoint sources of pollution. Aerial inventories were used to evaluate potential impacts of nonpoint sources of pollution on streams in the C1inch and Powe1. River watersheds (Sagona, 1990). Preliminary results indicate portions of the Clinch River watershed have significant soil. losses associated with urban development activities and eroding cropland and pastures. The Powel1. River watershed has a greater potential for soil loss from eroding agricultural lands, urban development activities, and coal mines. These nonpoint sources of pollution result in high concentrations of suspended solids in streams in the watershed after storms. These solids remain suspended as they are transported downstream until they reach Norris Reservoir, where impoundment slows the flow and allows them to settle and be deposited as sediment. Once deposited they reduce reservoir storage capacity, bury benthic organisms, and destroy fish spawning areas.

\section{Water Clarity}

Norris Reservoir has traditionally been considered a clear water reservoir compared to other IVA reservoirs. However, measurements of water clarity are mostly limited to inflow and forebay stations. Measurements of Secchi depth in the forebay of Norris Reservoir ranged from 4 to 12 feet with average light penetration of over 7 feet. Total dissolved solids and specific conductivity (measured as inflow) average $178 \mathrm{mg} / 1$ and $325 \mathrm{micromhos} / \mathrm{cm}$, respectively. Suspended solids were generally low (below $50 \mathrm{mg} / 1$ ). Values for dissolved solids are well within the 1 imit of $500 \mathrm{mg} / 1$ for domestic water supplies.

\section{Chemical Characteristics}

Norris Reservoir waters, based on inflow (PRM 65.4 and CRM 159.8) values, are moderately hard and well-buffered to a typical pH of 8.5 . Higher pH values (greater than 9.5) occur ocasionally near the surface, where photosythesis by algar removes carbon dioxide and carbonate from the water, thereby reducing the level of carbonic acid and increasing $\mathrm{pH}$. 
Total hardness derived largely from calcium and magnesium in the limestone rock throughout much of the drainage basin, averages $1.28 \mathrm{mg} / 1$, which is considered relatively hard water (on a scale of 1-60, soft; 61-120, moderately hard; 1.21-180, hard). Total sulfates average $48 \mathrm{mg} / 1$, which is moderately high for surface waters, and reflects effects of weathering of recently exposed minerals from mining operations in the watershed. Average alkalinity is $117 \mathrm{mg} / 1$, which is within the typical range for surface waters $(30-500 \mathrm{mg} / 1)$.

There are no known point sources of heavy metals in Norris Reservoir. Heavy metals occur naturally in surface waters in very low concentrations. Certain metals (including arsenic, cadmium, lead, and mercury) can be highly toxic to both humans and aquatic life at very low concentrations. Others (copper and zinc) are essential to life at low concentrations, but are toxic at only slightly higher levels.

In general, concentrations of heavy metals in inflows to Norris Reservoir are low. However, high concentrations of arsenic, cadmium, and lead have been measured several miles upstream of the reservoir. Total recoverable arsenic averaged less than $100 \mu \mathrm{g} / 1$, cadmium $1.8 \mu \mathrm{g} / 1$, 1ead $20 \mu \mathrm{g} / 1$, and mercury $0.5 \mu \mathrm{g} / 1$. Tutal recoverable copper and zinc averaged less than $10 \mu \mathrm{g} / \mathrm{L}$.

Particulate oxidized forms of iron and manganese are washed from soil and rocks by surface runoff. Dissolved (reduced) forms may cause undesirable water tastes, staining, scaling in pipes and boilers, or industrial processing problems. No harmful effects on human health are known to result from usual concentrations in water. Iron and manganese also make a small contribution to water hardness. Total iron and manganese concentrations in discharges from Norris Reservoir collected as part of the 1988 TVA drought study were low ranging from less than 0.01 to $0.10 \mathrm{mg} / 1$ and 1 ess than 0.005 to $1.30 \mathrm{mg} / 1$, respectively. Dissolved concentrations were less than $0.01 \mathrm{mg} / 1$ for irs and ranged from less than 0.005 to $0.97 \mathrm{mg} / 1$ for manganese. 


\section{Nutrients and Trophic Status}

Plant nutrient concentrations are low as measured in the lower end of Norris Reservoir. Total nitrogen and total phosphorus concentrations average $0.50 \mathrm{mg} / 1$ and 1 ess than $0.01 \mathrm{mg} / 1$, respectively; consequent $1 \mathrm{y}$, phytoplankton populations tend to be sparse. In the upper reaches in some embayments and inflows, nutrient concentrations up to $1.0 \mathrm{mg} \mathrm{N} / 1$ and $0.07 \mathrm{mg} \mathrm{P} / 1$ have been measured, which support higher levels of algal growth.

Norris Reservoir is ranked as an oligiotrophic (low productivity) tributary reservoir in the TVA system. This ranking was based on limited nitrogen, phosphorus, and chlorpphyll data collected in 1979 in the lower end of the reservoir. The more productive upper end and coves were not sampled. The 1979 trophic status study identified 83 phytoplankton taxa. Total abundance of blue-green algae was low compared to ot'ier tributary reservoirs. No zooplankton data are available. Surrounding terrestrial vegetation is rarely in contact with the water and aquatic macrophytes are not present.

\section{Bacteriological Water Quality}

Information describing the bacteriological quality of Norris Reservoir is 1 imited to data collected in 1974. Results at 8 recreation and public use areas indicated good bacteriological quality suitable for swiming and other, uses. A recreation assessment of the bacteriological water quality in Norris and other TVA reservoirs will be conducted in 1991 as part. of. TVA's reservoir monitoring program.

\section{Benthic Community (bottom dwe11ing organisms)}

Historically, the Clinch and Powell Rivers supported a diverse and abundant mussel fauna. Currently, mussel populations within the reservoir are probably limited to a relatively few species that are able to live in a lake environment. The demise of other species that probab1y inhabited this reach of river prior to impoundment is attributable to sedimentation and change in habitat. 


\section{Fish Populations}

Sixty-two fish species and three hybrids have been reported from Norris reservoir between 1949 and 1989 . Seventeen game fish species, 20 rough fish speciss, and 25 forage, or prey, species coinprized 19, 16, and 65 percent, respectively, by weight of total fish (shown in the figure below). A more equal distribution of these groups of fist was found during the past three years $(1987-1989)$.

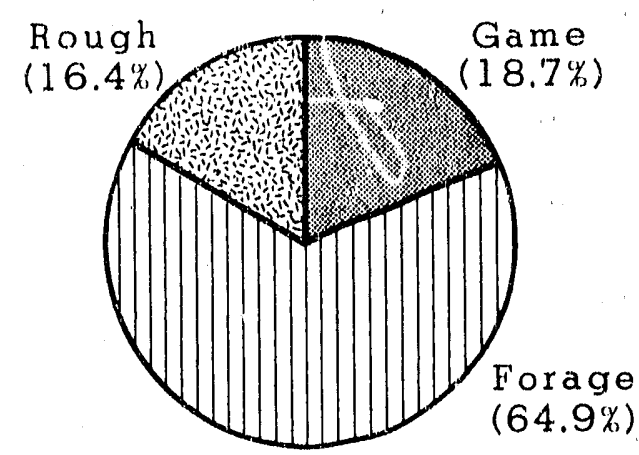

(a)

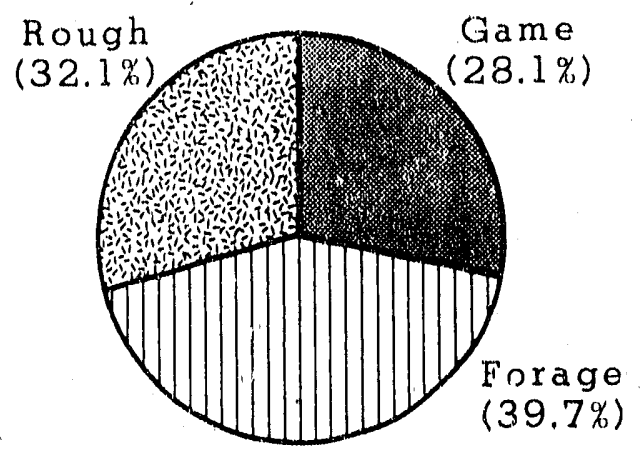

(b)

Mean distribution of fish biomass (pounds per acre) among major groups in Norris Reservoir based on (a) 101 cove rotenone samples taken between 1949 and 1989 and (b) 2 cove smaples taken each year from 1987 through 1989.

With an average standing stock of 166 pounds per acre of fish, Norris lanks 15 th among 19 Tennessee Valley impoundments (see following table). Only Ft. Patrick Henry, Watauga, Fontana, and Chatuge had less weight (biomass) of fish per acre. These data are based on all cove rotenone samples taken between 1949 and 1989 .

Dominant game species are bluegill; largemouth, sma1lmouth, and spotted bass; walleye; white bass; striped bass; and black and white crappie. Rough fish are dominated by carp, freshwater drum, channel and flathead catfish, suckers, and carpsuckers. Forage species are dominated by gizzard and threadt in shad. 


\begin{tabular}{|c|c|c|c|c|c|}
\hline \multirow[b]{2}{*}{ Reservoir } & \multirow[b]{2}{*}{ Inclusive dates } & \multicolumn{4}{|c|}{ Blomass (pounds per acre) } \\
\hline & & Game & Rough & Forage & Total \\
\hline Cherokee & $1949-1989$ & 69 & 113 & 607 & 789 \\
\hline Wheeler & $1949-1989$ & 110 & 205 & 361 & 676 \\
\hline Pickwick & $1949-1987$ & 54 & 115 & 217 & 386 \\
\hline Boone & $1953-1983$ & 51 & 58 & 245 & 354 \\
\hline Wilson & $1949-1983$ & 53 & 132 & 149 & 334 \\
\hline Kentucky & $1949-1982$ & 33 & 1.1. & 156 & 301 \\
\hline Me1ton Hil1 & $1964-1982$ & 20 & 152 & 126 & 298 \\
\hline Guntersvilie & $1.949-1988$ & 68 & 82 & 141 & 291 \\
\hline South Holston & $1951-1985$ & 59 & 62 & 161 & 281 \\
\hline F't'. Loudoun & $1949-1984$ & 43 & 79 & 157 & 279 \\
\hline Chickamauga & $1947-1989$ & 48 & 78 & 137 & 263 \\
\hline Watts Bar & $1949-1986$ & 28 & 115 & 89 & 232 \\
\hline Douglas & $1949-1983$ & 47 & 103 & 53 & 203 \\
\hline Nickajack & $1972-1981$ & 91 & 41 & 88 & 220 \\
\hline Norris & $1949-1989$ & 31 & 27 & 108 & 166 \\
\hline Ft. Pat. Henry & $1954-1.985$ & 19 & 69 & 57 & 145 \\
\hline Watauga & $1949-1984$ & 44 & 38 & 57 & 139 \\
\hline Fontana & $1949-1984$ & 35 & 30 & 32 & 97 \\
\hline Chatuge & $1953-1980$ & 42 & 9 & 7 & 58 \\
\hline
\end{tabular}

Threadfin shad, which were not in Norris until 1957, are utilizable as prey throughout their life span, whereas gizzard shad attain a larger size that is unavailabie to some predators. Threadfin shad were extirpated from Norris in the mid-1970's when parts of the reservoir iced over. After being stocked they reappeared in 1980 and developed a sustaining population, which has persisted through the present. Between 1984 and 1989 , numbers and pounds per acre of threadfin shad have doubled compared to their historical average whereas numbers and pounds per acre of gizzard shad during this recent time have decreased about 10 percent. Compared to more eutróphic reservoirs Norris has a relatively low forage fish base which limits the amount of predators the resurvoir can sustain.

Important game species are monitored annua11y by the TWRA to assess the status of the fishery and provide a basis for management decisions. Methods include cove rotenone, electrofishing, trap netting, seining, and creel surveys. Management strategies include primarily stocking, imposing size and creel limits, and constructing and maintaining $f$ ish 
attractors. The following description of game species is taken from TWRA's 1989 report (Peterson and Laue, 1989), interviews, and miscellaneous reports.

Black Bass. A size limit of 14 inches was placed on all three species of black bass in 1981 . This resulted in a disproportionate number of spotted bass (the smallest of the three species) in the bleck bass population and prompted removing the size limit on spotted bas's in 1986. Since 1986 the number of spotted bass harvested has increased, and it is hoped this increased harvest will result in a greater percentage of smallmouth and largemouth bass in the black bass population.

The majority of black bass are caught in the evening, after the daytime creel survey is completed, and thus the total, catch estimates are probably greatly underestimated. In addition, there are about six weekly wildcat tournaments and several small (e.g. company) tournaments held during the warmer months between May and 0ctober, results of which are not included in the creel. Although a popular reservolr, Norxis does not attract as many bass fishermen as the more eutrophic reservoirs in the area. Reasons probably include relatively smaller size of black bass, greater difficulty to catch them, and smaller populations. However, in response to concern over pollution in Watts Bar Reservoir, some fishermen have stopped fishing Watts Bar and begun to fish Norris. This indicates that for some fishermen quality of the fish is more important than catchability, and Norris has a reputation for having fish that are safe to consume.

An estimated 23,000 largemouth bass ( 36 percent of a11 black bass caught) were caught by anglers in $1989,3,774$ of which were harvested. Harvest rate (number of kept fish caught per hour) by bass fishermen was 0.03. Growth of this species is slower after the first two years than for largemouth bass in several nearby reservolrs, which probably reflects the smaller forage base in Norris. Summer sampling indicated that an excellent spawn occurred in 1989. 
Largemouth bass were autopsied for abnormalities in spring and fall $190 y$ in 19 reservoirs throughout the Valley. Norris ranked 6 th (1st being healthiest) out of 14 reservoirs sampled in the spring and 5 th out of 14 reservoirs sampled in the fall.

An estimated 24,126 smallmouth bass were caught by anglers in 1989 , resulting in a catch rate by all anglers of $0.07 \mathrm{fish}$ per hour and a harvest rate by bass fishermen of 0.02 per hour. Total estimated harvest of smallmouth bass in 1989 was 2,971 individuals. This value is low relative to the 1982 through 1986 harvest. However, numbers per acre of smallmouth bass increased greatly over the previous few years in the 1989 cove samples, indicating an excellent spawn occurred.

Angler harvest was greatest for spotted bass, even though conventional sampling methods indicater that this species was the least abundant black bass. Catch rate was $0.07 \mathrm{fish}$ per hour. Harvest rate by bass fishermen was $0.04 \mathrm{fish}$ per hour. Total estimated harvest was 5,764, more than twice as high as in any of the years between 1982 and 1988 .

Halleye. The walleye fishery has declined since about 1980 after $a$ few good years in the mid-1970s. However, the fishery appears to be improving since the drought ended in 1988. The spring of 1990 was apparently one of the best ever for walleye fishing. Divers and fishermen have reported seeing lots of young walleye in 1989 and 1990. These observations agree with results of cove sampling, which indicated a good spawn occurred in 1989.

The walleye population provides a limited but popular sport fishing resource. One walleye club exists in the area and hosts a nighttime tournament on Norris Reservoir the 2nd and $4 \mathrm{th}$ Friday of each month from the 4 th Friday of April through the 2nd Friday in October. During the first 10 tournaments in 1990 , a total of 700 pounds were caught, for an average harvest rate of 0.17 pounds per person per hour. A state enforced size limit for these tournaments does not exist; however the club has a minimum 14 inch size 1 imit. 
TWRA's reservoir-wide creel estimated the angler catch of walleye in 1989 at $7,369 \mathrm{fish}$, down from 10,560 in 1988. A relatively high percentage of these fish were harvested, 81 percent in 1989 and 86 percent in 1988. Catch rate by walleye fishermen was $0.14 \mathrm{fish}$ per hour in 1989 compared to 0.22 in 1988. As is the case with black bass, this creel underestimates total catch because it misses sumer nighttime fishing, including tournament fishing, which represents the majority of summer walleye fishing.

Although there is considerable fishing pressure in spring on the river above the reservoir, there are also a lot of fish caught in the lower end of the reservoir during the spawning season, which indicates spawning occurs in the reservoir as well as in the river. Currently, there is a $10 \mathrm{fish}$ creel limit on walleye. In sumer, walleye are found at the thermocline where both $D O$ and temperature are acceptable or at least tolerable.

Crappie. The crappie pofulation has declined greatly in recent years. An estimated 18,481 crappie were caught in 1989,91 percent of which were harvested. This was the first year on record that more black crappie (63 percent) were caught than white crappie. Harvest rate by crappie fistermen was $0.20 \mathrm{fish}$ per hour for white crappie and $0.32 \mathrm{fish}$ per hour for black crappie. Average size of white crappie creeled was 9.6 inches $(0.51 \mathrm{bs})$ and average size of black crappie creeled was 9.7 in $(0.6 \mathrm{lbs})$. A creel $1 \mathrm{imit}$ of $20 \mathrm{fish}$ was placed in effect in March 1989. However, the crappie population has been so low that only two or three individuals creeled have caught a limit.

Stocking of crappie by TWRA is being done in an attempt to enhance the fishery. In 1988, a total of 243,2041 - to 4-inch black crappie were stocked. The majority of these $f$ ish were raised in Doakes Pond, a subembayment of Davis Creek embayment on the Powell River arm of the reservoir. Stocking success using native black crappie is difficult to assess because the young produced by stocked brood fish cannot be differentiated from young of the native stock. To alleviate that 
problem stocking was continued in 1989 using blacknose black crappie, an Arkansas strain that has a unique external marking and was not present in Norris Reservoir. Using a fish with a unique mark was desirable in that the stocked fish could be differentiated from the native population of black crappie and thus their contribution to the creel could be determined. Blacknose black crappie brood $\mathrm{fish}$ were put in Doakes Pond after all other $f$ ish had been removed. High water prematurely allowed young-of-year crappie produced in Doakes Pond to escape to the reservoir before they could be counted. TWRA's best estimate of number of young crappie that entered the reservoir from Doakes Pond was 100,000. These fish were taken in trap nets in the fall of 1989 in numbers which suggest they could contribute significantly to the creel. None of the approximately 135,000 blacknose black crappie stocked in Cove Creek were taken in fall trap netting, which strongly suggests this stocking was unsuccessful. Doakes Pond was stocked again with blacknose crappie brood fish in 1990. The fall 1990 trap netting will reveal if there was a significant number of young produced.

Striped Bass. Striped bass were introduced into Norris Reservoir in 1966 and have been stocked most years since chen. Up until about 3 to 4 years ago Norris Reservoir produced numerous trophy stripers in the 40 50 pound range, and catches of $f$ ish in the 25 to 40 pound range were common. Norris' reputation for a trophy striped bass fishery attracted extremely heavy fishing pressure. In the past several years the striped bass $\mathrm{f} i$ shery has declined dramatically. This decline is seen in the reduced number and size of $f$ ish being caught and the reduced number of fishermen on the reservoir. The majority of fish caught now are in the 6 to 10 pound range. The rate at which fish are caught has become so low that many of the striped bass fishermen have stopped fishing Norris and changed to other lakes. Few 30-pound or larger fish are currently being caught, and a trophy-size fish from Norris at this time is 28 to 35 pounds.

TWRA's estimate of number of striped bass caught in 1989 was 7,309, of which 5,645 (77\%) were harvested. Number harvested was similar to 
that of 1988 but lower than the harvest from 1984 through 1986. These estimates drastically underestimate total catch since they are based solely on the daytime creel survey. The majority of striped bass fishing during the warm months takes place at night (much of the winter fishing is done during the day and is included in the creel).

Evidence for the decline in the striped bass fishery can be seen in the fewer number of guides currently operating. As recently as two years ago there were about 35 part-time or full-time guides operating on Norris Reservoir, but this number has dwindled to just a few.

Reasons for the decline in the fishery are probably a combination of extreme heavy fishing pressure for several years and a reduction in numbers stocked during 1986 through 1989. TWRA reduced the stocking rate in response to drought-induced decline in fertility.

Concern over the status of the fishery resulted in the growth to about 240 members of a recently formed organization called the Norris Lake Striper $\mathrm{Club}$, whose objectives include providing information that can be used in support of recommendations on managing the resource. Members are encouraged to keep records on date, size of fish caught, and hours fished. These data are stored on computer, analyzed, and made available to IWRA.

Throughout the history of this fishery there has been opposition from many non-striper fishermen, particularly crappie fishermen, who contend that the striped bass adversely affect the native sportfish fishery. Many of these fishermen would like to see stocking of striped bass discontinued or at: least more emphasis placed on management of the native species.

Bluegi11. Bluegill catch in 1989 was estimated to be 103,814 , of which $80 \%$ were harvested. This was the best year for bluegill fishing since 1982. Standing stock of bluegill (4,103 $\mathrm{f}$ ish per acre) greatly 
exceeded the historical average of $255 \mathrm{fish}$ per acre. Bluegill fishing should continue to be good in the next year.

White bass. An estimated 2,020 white bass were caught in 1989, compared to 5,356 in 1988 . The 1989 catch is the lowest since before 1982. Harvest rate for white bass fishermen was relatively high $(0.78$ fish per hour), indicating few people are fishing for white bass on Norris. Standing stock in 1989 was also less than the historical average.

Trout. Rainbow trout were first stocked in the Norris Dam tallwater in 1936 to create a coldwater fishery to replace the warmwatex fishery eliminated by the coldwater releases. From 1950 to 1970 trout were periodically stocked by the Tennessee Game and Fish Commission. A cooperative fishery management project between TVA, TWRA, and the US Fish and Wildife Service was conducted from 1971 through 1977, which included stocking and studies to evaluate conditions limiting cisvelopment of the fishery. TVA's Reservoir Releases Improvement Program was initiated in 1980 to address low dissolved oxygen, minimum flow, and other water quality problems associated with reservoir discharges. Improvements were made at Norris beginning at this time. Along with these modifications TWRA has stocked the tailwater with rainbow and brown trout. An estimated 254,120 trout weighing 82,282 pounds were harvested during an 11-year creel pertod between 1973-1977 and $1980-1985$.

\section{Fish Attractors}

The TWRA has a continuing program of constructing and replacing $f$ ish attractors made of brush piles and old tires. These attractors provide cover that is otherwise lacking when the reservoir is drawn down. Nine fish attractors covering 9.6 acres were constructed in the Flat Hollow section of the Powell River arm in 1.989. 
population of coldwater species and essentially preclude native warmwater species. Dissolved oxygen depletion in the cold bottom layer of water from which releases are drawn also limits aquatic 1 ife in the tailwater. Each year, dissolved oxygen concentrations are below $6 \mathrm{mg} / 1$ (the Tennessee criterion for trout streams) for about 56 days, below $5 \mathrm{mg} / 1$ (the Tennessee criterion for warmwater $\mathrm{fish}$ and other aquatic iffe) for about 28 days, and below $4 \mathrm{mg} / 1$ for about 7 days. In the fa11, dissclved oxygen normally decreases to $0.5 \mathrm{mg} / 1$ in the scrollcase; however, the attachment of baffles to the turbine hubs to increase turbulent aeration of releases added 2.5 to $3.3 \mathrm{mg} / 1$ of dissolved oxygen.

The on-and-off operation of Norris Dam for power generation causes high and low flows that further stress aquatic life in the tailwater. The reregulating weir below the dam has successfully maintained a minimum flow of $200 \mathrm{cfs}$ in the tailwater since 1984. 
Fioh Flesh Analysio

Five channe1 catfish were collected from each of three locations within Norris Reservoir (CRM 118.8, Cove Creek Mile 1.0, and PRM 34.0) in 1987 as part of a reservoir monitoring program to screen for toxica levels in fish from throughout the Tennessee Valley. Fillets from these fish contained low concentrations of priority pollutant metals, pesticides, and PCBs. Sampling for these pollutant's was also done in 1987 and 1988 upstream of Norris Reservoir (PRM 65.2) using individuals of a game, rough, and catfish species. Concentrations were low in all cases.

\section{Threatened and Endangered Species}

Many species that occur in parts of the Clinch-Powell watershed upstream of Norris Reservoir are 1 isted as endangered, threatened, or of special concern by Tennessee state agencies, various scientific groups in both Tennessee and Virginia, and the U.S. Fish and Wildiffe Service. Species listed as threatened or endangered by the TWRA and the U.S. Fish and Wildife Service are afforded legal protection. Because they are sedentary (bottom-dwelling) filter feeders, mussels are considered to be about the most susceptable aquatic species to pollution. Ten of the 50 specios of mussels in the Clinch and 6 of the 37 in the Powell Rivers are included on one or more of the endangered, threatened or special concern 1ists. Nonpoint sources of pollution, especially runoff and siltation from mining and agricultural operations, are considered to have the largest impacts on the mussels in these rivers.

\section{Releases from Norris Reservoir}

Releases from Norris Reservoir are highly variable in temperature, dissolved oxygen, and flow rate. Because releases for power generation are drawn from the deep, cold layer of water in the reservoir, temperatures of releases range from about $42^{\circ} \mathrm{F}$ in winter to about $68^{\circ} \mathrm{F}$ in $3 y^{1} \mathrm{y}$ fall, with daily variations from 9 to $16^{\circ} \mathrm{F}$. These temperatures support a healthy "put, grow, and take" coldwater fishery for rainbow and b"own trout, but they do not support a reproducing 
Norris Reservoir provides the region with many environmental and economic benefits. The water quality conditions of Norris Reservoir are suitable for all the uses presently identified by the Tennessee Department of Health and Environment, including domestic water supply; industrial water supply, fish and aquatic life, recreation, irrigation, and livestock watering and wildife. However, several conditions affect the beneficial uses of Norris Reservoir.

Low dissolved oxygen levels, in both the deep layer of water in the reservoir and in releases of that water to the tailwater below the dam, fluctuations in water level in both the reservoir and tailwater, and variable flow rate in the taj.lwater are perhaps the most significant conditions affecting the uses of Norris Reservoir and its tallwater. These conditions occur frequentiy, are severe, and may affect several uses. Other conditions, mainly sediment loads from various land uses potentially affect the beneficial uses of Norris Reservoir.

\author{
Condition \\ Low dissolved oxygen \\ in hypolimnion and \\ in reservoir releases \\ Intermittent releases \\ Pool leve1 fluctuations
}

Sedimentation

Shoreline development
Use (s) affected

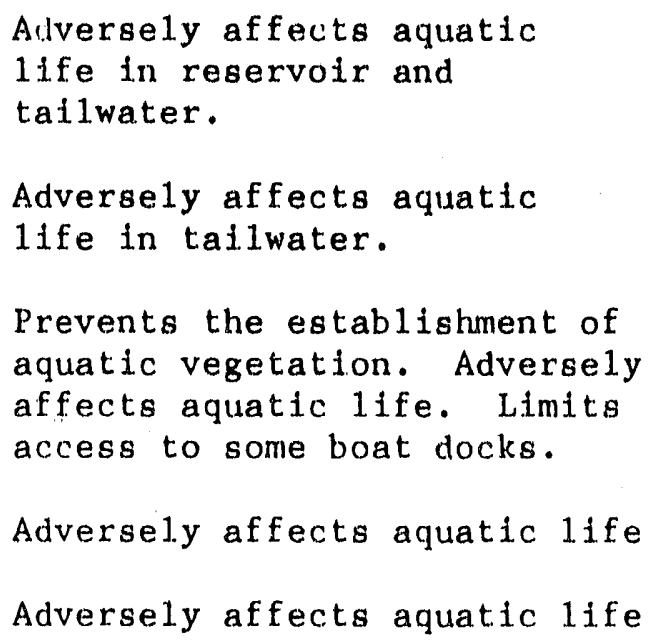




\section{SELECTED RESERVOIR MANAGEMENT AGENCIES}

Several agencies and organizations are actively involved in protecting the health and integrity of Norris Reservalr. These organizations investigate and monitor the reservolr, attempt to mitigate those conditions inpairing its uses, and provide information to improve public understanding and awareness of reservoir conditions. A number of those organizations are 1 isted below. They provide information and assistance geared to the varying needs of the region they serve.

Citizens League for Environmental Action on Norris Lake (C.L.E.A.N.) is a lake users group whose goal is to protect the water quality of Norris Reservoir and its tributaries.

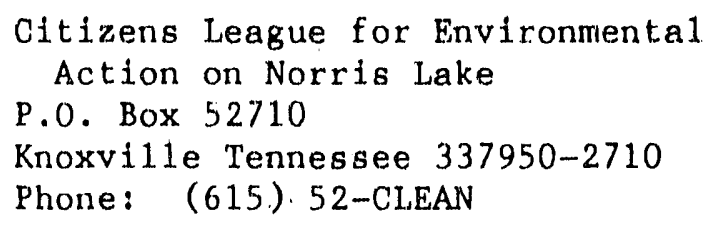

The Tennessee Department of Conservation has responsibility for state parks on Norris Reservoir.

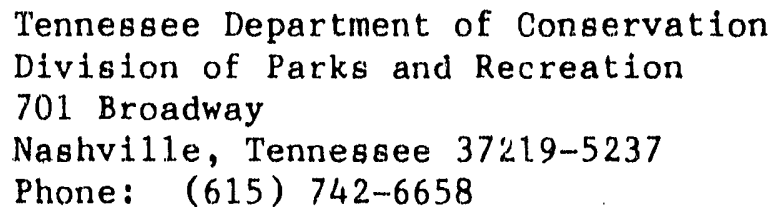

The Tennessee Department of Health and Environment is the primary environmental regulatory agency in Tennessee. It determines water use classifications, criteria, and standards and issues permits for wastewater discharges. It also regulates water supplies, solid and hazardous waste, and air quality. The Knoxville basin office in Knoxville, Tennessee, has responstbility for Norris Reservoir area.

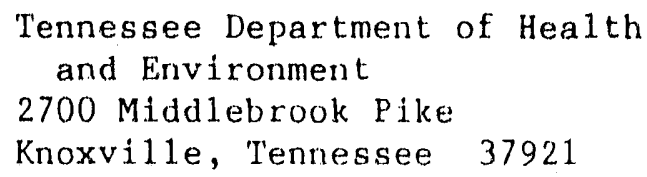


The Tennessee Valley Authority Water Resources Division manages the dally operations of Norris Reservolr, conducts water quality and aquatic resource monitoring and assessment programs, and develops water quality management plans. The Land Resources Division manages TVA lands and recreation sites along the reservoir and develops reservoir land-use plans.

Tennessee Valley Authority

Water Resources Division

Evans Building

Room 1W 141A

Knoxville, Tennessee 37902--1499

Phone: (615) 632-6770

\author{
Tennessee Valley Authority \\ Eastern Land Resources \\ District office \\ 26.11 Andrew Johnson Highway \\ Morristown, Tennessee $3781 / 4$ \\ Phone: (615) 587-5600
}

The Tennessee Wildife Resources Agency is responsible for fish and game regulations, fish stocking, boating regulations, and boat launching ramps. The regional of fice in Talbott, Tennessee, is responsible for Norris Reservoir.

Tennessee Wildlife Resources Agency

6032 West Andrew Johnson Highway

Talbott, Tennessee 37877

Phone: (615) 587-7037

The U.S. Department of Agriculture is responsible for on farm soll conservation acrivities. Various district conservationists located in county offices are responsible for the Norris Reservoir Area.

The U.S. Environmental Protection Agency is responsible for the implementation of the Clean Water Act and oversees federally mandated programs managed by the states. The Region IV office in Atlanta, Georgia, serves the Norris Reservoir area and all of the southeastern United States.

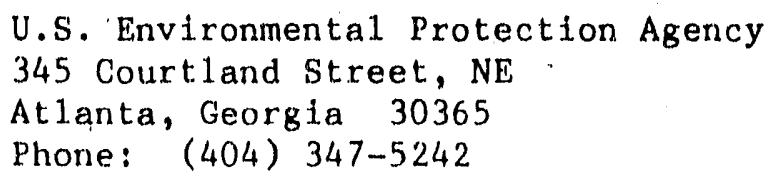

The U.S. Fish and Wildife Service is responsible for ensuring the protection of $\mathrm{fish}$ and wildife and their habitats during federally sponsored or permitted development activities and has responsibility for the identification of threatened and endangered species. The regional office in Cookeville, Tennessee is responsible for the Norris Reservoir area.

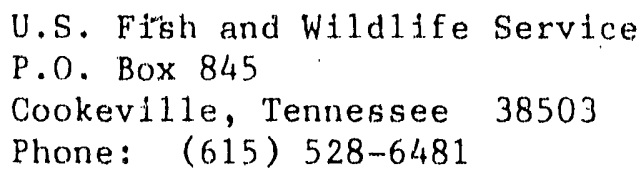


Cable, S. and L. Norris. 1988. "An Exploratory Social Survey: Pub1ic Perceptions of Water Quality Issues in selected Communties in the C1inch-Powe11 Watershed Area," The University of Tennessee, Knoxville, Tennesgee for the Environmenta1 Quality Staff, Tennessee Valley Authority, Knoxville, Tennessee. Contract Number TV 73373A.

Placke,' J. 1983. "Trophic Status Evaluation of IVA Reservoirs," Report No. TVA/ONRED/WR-8317, Tennessee Valley Authority, Division of Services and Field Operations.

Perry, J. B. 1988. "LaFollette, Tennessee, Water Supply Study," Rr port No. WR 28-2-580-124, Tennessee Valley Authority, Engineering Laboratory.

Peterson, D. C. and D. E. Lane. 1989. Norris Reservoir Annual Report. Tennessee Wilditfe Resources Agency (Inhouse Report)

Ruane, F.J. ,et al. 1989. "Tallwater Management for Beneficial Uses," Waterpower 189 Proceedings International. Conf. on Hydropower, U.S.Army Corps of Engtneers/ASCE Niagara Fal1, New York.

Sagona, F. 1990. "Assessment of Aerial Inventory of Land Use and Nonpoint Pollution Sources in the Clinch and Powell River Watershed," In Progress, Tennessee Vallley Authority, Water Quality Department.

Shiao, M. C., et al. 1986. Modeling of Clinch River Water Quality In the Norris Dam tailwater. Tennessee Valley Authority, Division of Air and Water Resources, Engineering Laboratory. Report No. WR28-1-590-126.

Tennessee Department of Health and Erivironment. 1988. "The Status of Water Quality in Tennessee. 305(b) Report, Office of Water Management, Nashville, Tennessee.

Tennessee Valley Authority. 1963. C1inch-Powe11 Valley: Summary of Resources with Inventory Supplements. $221 \mathrm{pp}$.

- 1990. "Tennessee River and Reservoir System Operation and Planning Review." Draft Environmental Impact Statement. Tennessee Valley Authority, Knoxville, Tennessee.

Tennessee/Virginia Joint Task Force. 1987. "Conserving the Unique Values of the C1inch and Powell Rivers," A draft report to the governors of Virginia and Tennessee.

Trimb1e, S. W., and W. P. Carey. 1984. Sediment Characteristics of Tennessee Streams and Reservoirs, U.S. Geological Survey, Report No. 84-749.

Virginia Cooperativer Extension Service. 1986. "The C1inch, Powe11, and Holston Rivers of Virginia and Tennessee: Wildlife and Water Quality," Publication 460-110. U.S. Department of Agriculture, Blacksburg, Virginia.

Yeager, B., et a1. 1987. "Effects of Aeration and Minimum Flow Enhancement on the Biota of Norris Tailwater," Report No. TVA/ONRED/AWR $87 / 41$, Tennessee Valley Authority. 


\title{
ACKNOWLEDGMENTS
}

This work was funded by Federal appropriations to the Tennessee Valley Authority (IVA) for water resources management. This report was prepared by members of a project team of the Water Resources Division of TVA with other TVA staff assigting.

Your comnents and suggestiong are important to us! They help us better meet the information needs of reservoir users. Comments, suggestions, and requests for additional coples of this report should be directed to:

\author{
Larry R. Clark \\ Water Quality Department \\ Tennessee Valley Authority \\ Haney Building, Room 2S 270C \\ 311 Broad Street \\ Chat tanooga, Tennessee 37402-2801 \\ Phone: (615) 751-7331
}

TVA is an equal opportunity and affirmative action employer. TVA also ensures that the benefits of programs receiving TVA financial assistance are available to all eligible persons regardless of race, color, sex, national origin, handicap, or age. 

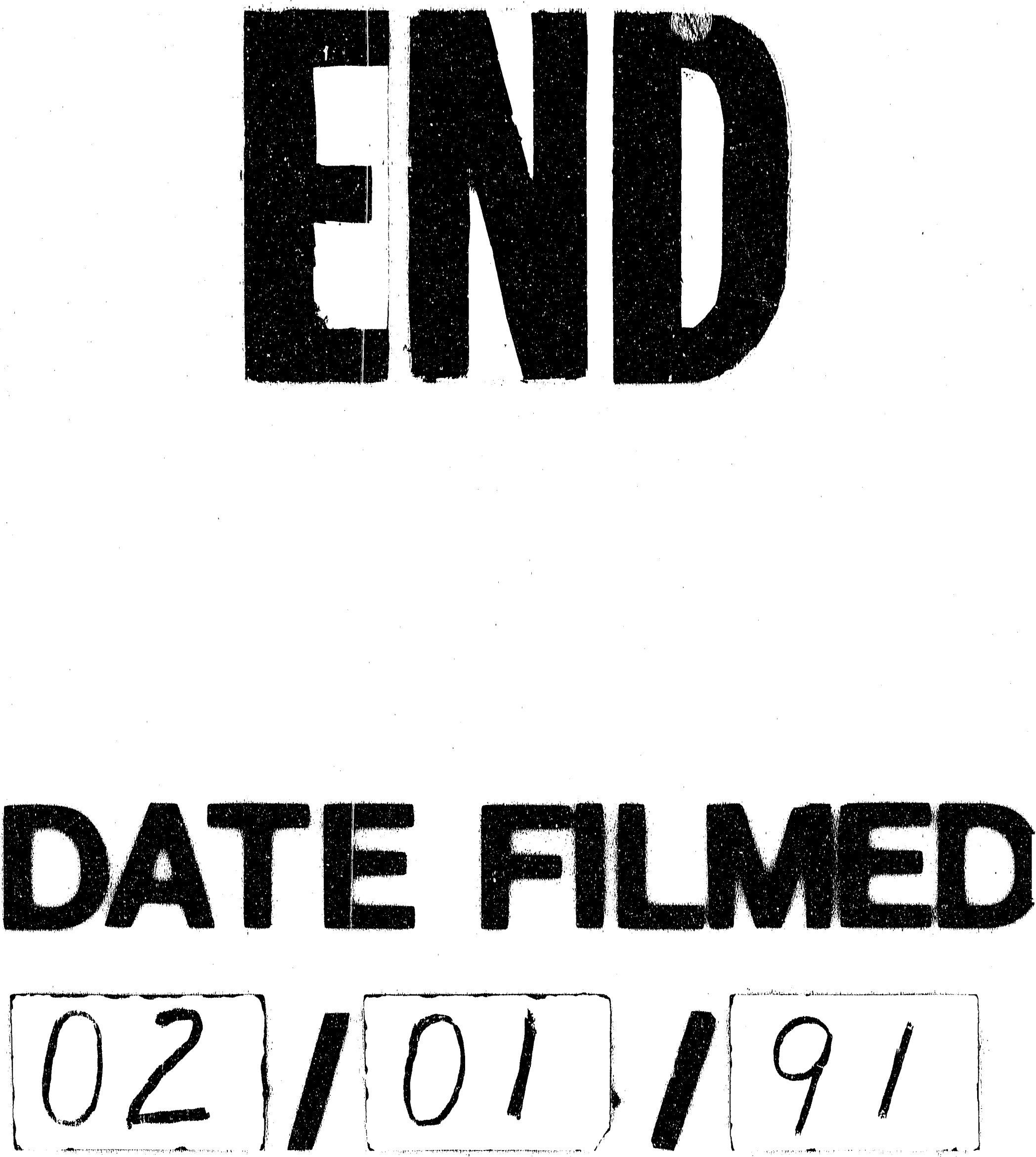
